\title{
Views of secondary school students on ideal teacher qualifications: A phenomenological analysis
}

\author{
Fatma Kalkan ${ }^{1}$, Emine Dağlı \\ ${ }^{1}$ Martyr Teacher M. Ali Durak Secondary School, Turkey \\ ${ }^{2}$ Department of Primary Education, Hatay Mustafa Kemal University, Turkey
}

\begin{abstract}
Article Info
Article history:

Received Mar 5, 2020

Revised Dec 17, 2020

Accepted Jan 30, 2021

Keywords:

Ideal teachers

Phenomenology

Secondary school students

ABSTRACT

This research aimed to reveal the views of secondary school students on ideal teacher qualifications. For this purpose, research was carried out in a phenomenological pattern, which is one of the qualitative research methods. The study was carried out with 76 students who were studying in a secondary school in the 2017-2018 academic year. The data were obtained with the repertory grid technique and interview technique. As a result of the analysis of the data, it was seen that the qualifications of the teachers considered ideal by the participants were among the general competencies of the teaching profession. According to the results of this research, ideally, teachers are expected to provide good and fun lessons, not discriminate among students, be friendly and calm in communications with students, and ensure discipline and democracy in the classroom environment.
\end{abstract}

This is an open access article under the CC BY-SA license.

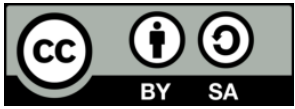

\section{Corresponding Author:}

Fatma Kalkan

Martyr Teacher M. Ali Durak Secondary School

Kordonboyu Street No.1, 06180 Yenimahalle/Ankara, Turkey

Email: fatmaturan2007@hotmail.com

\section{INTRODUCTION}

The human development process starts in the family and continues into the neighborhood, school, and business life, encompassing the entire life of the individual [1]. This process is expressed through education, and individuals receive various benefits directly or indirectly through education. It is only possible for effective education in schools for individuals of all ages to be self-actualized through in-school and outof-school experiences that will benefit society [2]. To realize effective teaching, basic elements such as the school, classroom, program, teacher, and technology. are needed. However, contrary to what is believed, class size and other physical facilities remain secondary to the quality of teaching [3]. The most important factor in effective teaching in a school is the teacher. The characteristics of the teacher and the behaviors she or he exhibits determine the qualities of effective teaching.

To realize effective teaching, the characteristics of the teacher and the behaviors that the teacher should have are the most important topics for all stakeholders (educational scientists, politicians, practitioners, parents, students) who are interested in education and studies being carried out on this subject. In these studies, teachers' characteristics and behaviors that they exhibit are addressed within categories of "competency," "quality," "standards," and "qualification," and occasional interchangeability causes concept confusion [4]. Problems such as the fact that concepts that are used interchangeably in different countries cannot be used with the exact meaning, the change in the meaning brought to concepts over time, and the differences in the expectations related to a concept (e.g., academic or political) are among the reasons for this confusion. It will now be helpful to address the meanings attributed to these concepts to clarify this confusion. 
The concept of "efficacy" is expressed in both English and Turkish as competency, effectiveness, and quality [5]. With the discussions on the use of these concepts in the literature, the notion of competency for teachers is understood as the belief in their strength for success in teaching; effectiveness implies action that must be shown on the way to success, and the level of these two qualities together is regarded as the basic competency measure [6]. Quality refers to the whole of knowledge, skills and abilities, and in business life, it is seen or expressed as a set of features when a job is successfully performed [5, 7]. Quality, qualifications, and competencies are associated with learning outcomes. The European Commission defines learning outcomes as: The set of knowledge, skills and/or competences an individual has acquired and/or is able to demonstrate after completion of a learning process [8].

Teacher competencies are a concept used in applications before the 1990s, whereby teachers' attitudes, knowledge, and skills [9] were listed in detail to help them perform their profession effectively and efficiently. Since the beginning of the 1990s, teaching standards have been used instead of this concept. In essence, both concepts have the same meaning and differ in terms of coverage. Competencies usually include details of what the teacher can do at the behavioral level, although standards do not go down to the behavioral level. In this regard, standards include simpler and more general expressions than competencies do [10].

The competencies of the teaching profession are determined by relevant institutions and organizations within the framework of the educational policies of countries. The definition of the competencies of the teaching profession in Turkey is carried out by the Ministry of Education. General competencies of the teaching profession were first introduced in 2002 by the Ministry of National Education's General Directorate of Teacher Training and Education and they have undergone many changes in the process. Most recently, they were updated in 2017 to comply with the national and international regulations in education. General competencies of the teaching profession after this update consist of three competency areas including "professional knowledge," "professional skills," and "attitudes and values" and 11 sub-competencies related to these competencies (knowledge of the specific field, knowledge of the education field, knowledge of legislation, planning of teaching, creating learning environments, managing the teaching and learning process, measurement and evaluation, attitude towards the student, national/spiritual/universal values, communication and collaboration, personal and professional development) and 65 performance indicators [9].

Teacher qualifications can be defined as the totality of the knowledge, skills, and competencies that teachers need to achieve to successfully fulfill their teaching tasks, which they have achieved in the course of a learning process. Due to the roles of teachers in education, academic studies are carried out around the world to determine and increase the qualifications of teachers. Teacher qualifications, which are thought to be found in all teachers based on the conditions required for effective teaching, are expressed in different ways. A teacher who does not have the knowledge and skills to effectively manage the teaching process will inevitably not exhibit effective teaching behaviors [11]. For this purpose, the ideal teacher should have enough knowledge about the field in which s/he is educated, gain knowledge of the teaching profession, and be equipped with the skills related to teaching. An ideal teacher is associated with the classroom management approach [12]. The success of the teacher in the education process is related to classroom management and those who are in control of the classroom have the qualifications of an ideal teacher. Ideal teachers for effective teaching are expected to have some personal characteristics as well as professional knowledge and skills. Ideal teachers should be friendly, tolerant, loving, trustworthy, honest, objective, and confident towards the student; they should be models for students with their ideas and behaviors [13]. The ideal teacher should be informative, love the profession, be able to speak the language properly, be knowledgeable, communicate well, and be democratic [14].

It is possible to come across some studies conducted on the qualifications of the ideal teacher and sort these into two groups as quantitative and qualitative. In quantitative studies, student achievement is considered as an indicator of effective teaching. In this respect, teachers' characteristics, pedagogical content knowledge, professional knowledge, skills and experiences, professional development, professional competency constructs, and satisfaction are presented with standardized tests that measure student success [15-26]. In qualitative studies, the views of individuals about the characteristics of an effective teacher or qualifications of an ideal teacher are revealed through various methods, techniques (such as phenomenological patterns, grid technique), and they are interpreted based on theories [4, 27, 28]. Studies reveal views on ideal teaching as well as the qualifications and behaviors of the ideal teacher [29-32].

One of the theories is the personal construct theory (psychology), which tries to explain why people's attitudes towards world events are different. The basic starting point of the personal construct theory is cognitive structure [33]. People have constructs about anything and everything [34]. Cognitive constructs consist of schemes on how to perceive new knowledge in any learning situation, how to relate to existing knowledge, and how to construct it in the mind. Constructs direct one's perspective and control his/her 
behavior in the final sense [35]. New knowledge and experience are effective in the formation and change of the individual's cognitive construct. Individuals use various constructs to express the dimensions and phenomena of experiences that form their inner worlds. These are emotions, thoughts, and so on [5]. Depending on their experience, the construct of a particular cognition (or case) is bipolar. For example, the construct 'warm' could have many bi-polar opposites: 'cold', 'un-friendly' or 'uncomfortable'. Constructs are like 'a pair of goggles' through which we view sections of the world [35]. As a result of knowledge and experience, individuals communicate through these cognitive constructs that they form in their inner world and try to understand the world [36]. Individuals' cognitive constructs related to a concept or phenomenon are closely related to their views. Therefore, revealing the cognitive constructs of individuals about that concept or phenomenon will provide us with information about their views on that concept or phenomenon.

In the literature, when studies are examined, it is seen that the qualifications of the ideal teacher are mostly expressed at standard levels and studies do not contain in-depth information about the behavior dimension of the ideal teacher [37-41]. On the other hand, in the studies conducted based on the personal construct theory, although it provides detailed information about the qualifications of the ideal teacher, these qualifications are determined by educational practitioners (i.e., school administrators, teachers, teacher candidates) [5, 33, 42]. However, students are in direct communication with the teacher in the teaching process. The students observe the personal characteristics, attitudes, and behaviors of their teachers in the teaching process and form cognitive constructs related to the ideal teacher by comparing them with other teachers. These cognitive constructs need to be analyzed for revealing the views of students related to ideal teacher qualifications. The views of students related to ideal teacher qualifications, effective teaching, determining the required teacher qualifications, and revealing teacher competencies can provide important contributions to the evaluation of the content of teacher training courses and classroom management courses for prospective teachers or the evaluation of the in-class performances of prospective teachers. These views can also shed light on the studies of educational scientists and politicians in the establishment of professional development monitoring and evaluation systems. Therefore, the focus of this study is to reveal the cognitive constructs of secondary school students related to ideal teacher qualifications through Kelly's personal construct theory.

\section{RESEARCH METHOD}

This study aimed to reveal the views of secondary school students related to ideal teacher qualifications. In this respect, a phenomenological pattern was used from among qualitative research designs. Phenomena can be seen in different ways, such as events, experiences, constructs, orientations, concepts, and situations in the world we live in [43]. In this approach, the researcher examines the meanings that the individual imposes on a phenomenon. The phenomenological study defines the common meaning of several people's lived experiences with the phenomenon or concept [44]. It is important to define phenomena and to not generalize in phenomenology [45].

\subsection{Study group}

The study was carried out with 76 students who were studying in a secondary school in the 20172018 academic year. The criterion sampling method was used in deciding the study group. Criterion sampling is the creation of a sample from individuals, events, objects, or situations with qualifications identified about the problem [46]. In the research, it was taken as the criterion that students should have received at least one year of education from six teachers, where they identified three as ideal and three as non-ideal. With this criterion, it was assumed that the students would be familiar enough with the teachers to group them as ideal and non-ideal. Therefore, 5th grade students are excluded from the research. The demographic characteristics of the study group are given in Table 1.

Table 1. Demographic characteristics of the study group

\begin{tabular}{ccccc}
\hline \multirow{2}{*}{ Gender } & \multicolumn{4}{c}{ Grade } \\
& 6th grade & 7th grade & 8th grade & Total \\
\hline Female & 24 & 15 & 18 & 57 \\
Male & 4 & 8 & 7 & 19 \\
Total & 28 & 23 & 25 & 76 \\
\hline
\end{tabular}

Of the participants, 57 were female and 19 were male; 28 were in the 6 th grade, 23 were in the 7 th grade, and 25 were in the 8 th grade. A total of nine volunteer students, three from each grade level, were interviewed. Of these students, six were female and three were male. 


\subsection{Data collection}

In this study, data were obtained by two different techniques: the repertory grid technique and the interview technique. "Grid" is a generic term for a series of simple assessment scale procedures. It is used to reach definitions that describe how a person sees the world or a smaller portion of it [47]. The repertory grid technique, which is based on Kelly's personal construct theory, is a method derived from personal constructs and factors, revealing the hidden and informal theories underlying experiences [34]. Individuals use their constructs to understand and interpret the events that occur in their environment, and these constructs are shaped by the individual's experiences. Thus, individuals begin to understand the world in which they live by developing a personally organized interpretation system based on their experiences [48]. Constructs are part of this system and are located on two opposite poles. In the repertory grid technique, the positioning of the constructs that individuals develop based on their experiences is important for analysis [49].

The repertory grid form was developed according to the triple repertory grid technique [50] to determine the cognitive constructs of secondary school students related to ideal teacher qualifications. According to the repertory grid technique, data are obtained gradually $[50,51]$. In the first stage, the students were told to think about the teachers who taught their classes. The students were then asked to choose three ideal and three non-ideal teachers from among the teachers they thought of. In the second stage, the students were asked to set a code name for these teachers and place them in the corresponding sections in the triple repertory grid form. In the third stage, ideal and non-ideal teachers were shown on a chart in ten different ways in the triple combination. The students were asked to answer the following question: "To you, what common characteristic or qualification (excluding physical features) do two of the three teachers have that is different than the other?" Following the answers of the students, 10 two-dimensional cognitive constructs consisting of words, adjectives, or sentences were obtained. In the fourth stage, the students were asked to score the six teachers they chose regarding the qualifications/cognitive constructs they determined (5 being the most desirable in terms of qualification and 1 being the least). Repertory grid forms took 60-80 minutes to complete. The data to be included in the analysis were determined by considering the understanding of the repertory grid technique, filling out the interview form properly, understanding the scoring logic in the repertory grid technique, and not having copied the forms. The first five cognitive constructs and calculation of points from a form completed by 7th grade student are shown in Table 2 as an example.

Table 2. Completed sample repertory grid form by 7 th grade student

\begin{tabular}{|c|c|c|c|c|c|c|c|c|}
\hline $\begin{array}{l}\text { Ideal teachers' } \\
\text { qualifications }\end{array}$ & Red & Blue & Green & Black & Yellow & Purple & $\begin{array}{l}\text { Non-ideal teacher } \\
\text { qualifications }\end{array}$ & Total \\
\hline $\begin{array}{l}\text { 1. S/he provides silence } \\
\text { during the lesson. }\end{array}$ & $\Delta 4$ & $\Delta 4$ & 4 & $\Delta 1$ & 1 & 1 & $\begin{array}{l}\text { 1. There is a lot of noise } \\
\text { in the classroom. }\end{array}$ & 15 \\
\hline $\begin{array}{l}\text { 2. S/he does not reflect } \\
\text { private life problems in the } \\
\text { class. }\end{array}$ & 3 & $\Delta 4$ & $\Delta 4$ & 1 & $\Delta 1$ & 1 & $\begin{array}{l}\text { 2. If s/he is depressed, } \\
\text { s/he screams in the } \\
\text { classroom. }\end{array}$ & 14 \\
\hline $\begin{array}{l}\text { 3. S/he teaches along with } \\
\text { jokes. }\end{array}$ & $\Delta 3$ & 2 & $\Delta 3$ & 1 & 1 & $\Delta 1$ & $\begin{array}{l}\text { 3. S/he has no sense of } \\
\text { humor. }\end{array}$ & 11 \\
\hline 4. S/he treats us equally. & $\Delta 2$ & $\Delta 4$ & 3 & 1 & $\Delta 1$ & 2 & $\begin{array}{l}\text { 4. S/he likes some of us } \\
\text { more }\end{array}$ & 13 \\
\hline $\begin{array}{l}\text { 5. When something } \\
\text { happens, s/he does not } \\
\text { think "s/he is lazy, so it is } \\
\text { expected }\end{array}$ & 1 & $\Delta 2$ & $2 \Delta$ & 1 & 1 & $\Delta 1$ & $\begin{array}{l}\text { 5. "Laziness is always } \\
\text { guilty," s/he thinks }\end{array}$ & 8 \\
\hline
\end{tabular}

The interview technique used in qualitative research serves the purpose of revealing the perspectives of the people and seeing the world through their eyes [52]. In qualitative interviews, it is essential to obtain in-depth information about people's views, feelings, and thoughts about a subject [53]. Individual interviews were also conducted with the participants to fully understand what the participants meant by cognitive constructs, to obtain more in-depth information, and to make analyses more accurate. During these interviews, a semi-structured interview form prepared by the researchers was used. The questions on the interview form were examined by two experts working in the field of Turkish language in terms of understandability and were rearranged in line with the recommendations of the experts. The main question of the interview form was "Would you explain the qualifications of a teacher (or teachers) that you consider ideal?" However, additional questions were asked of the participants to better analyze some of the cognitive constructs that were not understood in the repertory grid forms and expressed by the participants. 


\subsection{Data analysis}

A descriptive analysis method was used for data analysis. According to this approach, the data are summarized and interpreted in advance according to predetermined themes. In descriptive analysis, direct quotations are frequently used to reflect the views of the individuals interviewed or striking observations [43]. The data obtained by using the grid technique were processed in four stages by the descriptive analysis method. The first stage of the data analysis process was the naming of cognitive constructs. A total of 1520 cognitive constructs for ideal and non-ideal qualifications were collected from the forms administered to students. However, since the purpose of the study was determining ideal teacher qualifications, negative cognitive constructs were excluded from the analysis and 760 positive cognitive constructs were studied. At this stage, cognitive constructs were analyzed by classification according to similarities and common characteristics. The general evidence obtained from the data indicated that cognitive constructs refer to the general competencies of the teaching profession. In this context, cognitive construct groups consist of the teaching profession's competencies. Similar to the three general competencies of the teaching profession, three cognitive construct groups should be obtained. However, professional knowledge and professional skills were considered as a single competency, namely "professional knowledge and skills," since some of the cognitive constructs of the participants about these competencies of ideal teachers were so interrelated that they could not be separated from each other with clear lines. Thus, two cognitive construct groups, "professional knowledge and skills" and "attitudes and values," were obtained. All participants produced 10 cognitive constructs, at least one in both cognitive construct groups, and 760 cognitive constructs were classified within these two cognitive construct groups.

Determining which cognitive constructs correspond to a teaching profession competency area would ensure that cognitive constructs groups are correctly formed. For this reason, in the second stage, we aimed to determine which cognitive constructs may come in response to which of the indicators of sub-competencies. In the third stage, it was tried to determine the cognitive constructs matching the competencies of professional knowledge and skills and attitudes and values. In this way, cognitive constructs were also matched with cognitive construct groups. To create a cognitive construct group, at least three participants were required to express the same or similar cognitive construct and all 760 cognitive constructs were included in the analysis. The fourth and final stage of the data analysis process was the statistical analysis of the data. In this stage, the cognitive construct rankings as scored by the participants were taken into consideration and the first cognitive constructs were multiplied by 10; the other cognitive constructs were multiplied by numbers from 10 to 1 and then the final scores were obtained. Then, using the Microsoft Excel program, the total and arithmetic mean of these results were calculated.

Descriptive analysis was also used in the analysis of the data obtained with the interview technique. When the answers given by the participants to the question of "Would you explain the qualifications of a teacher (or teachers) that you consider ideal?" were examined, it was seen that the qualifications of the teachers considered as ideal corresponded to the general competencies of the teaching profession. Therefore, they were classified within professional knowledge and skills or attitudes and values, similar to the cognitive construct groups.

To better analyze some cognitive constructs expressed by the participants and not understood in the repertory grid forms, during these interviews, the participants were asked what they would like to explain with these cognitive constructs. For example, the participants were asked "What is discipline?" and "Who is a disciplined teacher?" An answer given to this question was: "They ensure discipline and silence in the classroom." When the participant's views and indicators of sub-competencies were examined, it was seen that the "disciplined" cognitive construct could be included in both creating learning environments and managing the teaching and learning process, which are sub-competencies of professional skills. Thus, the "disciplined" cognitive construct was matched with the professional knowledge and skills cognitive construct group.

\subsection{Validity and reliability}

Proximity to the research area, gathering detailed and in-depth information through face-to-face interviews, collecting data in the natural environment where the event takes place, collecting long-term information, being able to go back to the area for confirmation of the findings, and gathering additional information are among the features that provide validity in qualitative research [43]. In this direction, the steps taken to ensure the internal validity of this study were: 1) The study was carried out in a school where one of the researchers worked, which provided the researchers with the opportunity to collect data for a long time through face-to-face interviews in the natural environment. This also enabled the researchers to understand the data correctly and to confirm the findings; 2) The data obtained from the natural environment were presented in the findings section, and the cases they were related to being interpreted according to the grade level and developmental characteristics of the participants were presented. To ensure the external 
validity of the study, detailed information about the criteria to be included in the selection of the participants for the study group, the process of including the participants in the research, the data collection tool, and the analysis are given.

To ensure the internal reliability of the research, the findings obtained from the analysis of the data of step 1) were given directly without interpretation. For the analysis of step 2) data, the theoretical structure was formed by the general competencies of the teaching profession. Cognitive construct groups were determined based on the general competencies of the teaching profession. To determine whether the matching of cognitive constructs with cognitive construct groups determined within the framework of general competencies of the teaching profession was correct, expert opinion was consulted. Cognitive constructs, general competencies of the teaching profession, sub-competencies, and indicators of sub-competencies were given to a faculty member from the department of educational sciences. The instructor was asked to match the cognitive construct groups with cognitive constructs according to the general competencies of the teaching profession. The matching of this instructor and the cognitive construct groups of the researchers were then compared. The same method was followed in the analysis of the data obtained from the interviews. According to the calculations made for internal reliability [54], the consistency rate between the matchings was $91 \%$. To ensure the external reliability of the research, subjects related to the method such as data collection, analysis, combining, and presenting the results of the analysis are explained in detail.

\section{RESULTS AND DISCUSSION}

\subsection{Participants' cognitive constructs related to ideal teacher qualifications}

As a result of the analysis of the data obtained from the repertory grid forms, the participants produced 760 cognitive constructs related to ideal teacher qualifications. The cognitive constructs were classified within the professional knowledge and skills and the attitudes and values cognitive construct groups. The number (frequencies) and percentages of the cognitive constructs in each cognitive construct group are presented in Table 3.

Table 3. The number and percentages of the cognitive constructs in cognitive construct groups

\begin{tabular}{|c|c|c|c|c|c|c|c|c|}
\hline \multirow[b]{2}{*}{ Cognitive construct groups } & \multicolumn{2}{|c|}{ 6th grade $(n=280)$} & \multicolumn{2}{|c|}{ 7th grade $(n=230)$} & \multicolumn{2}{|c|}{ 8th grade $(n=250)$} & \multicolumn{2}{|c|}{ General $(n=760)$} \\
\hline & $\mathrm{n}$ & $\%$ & $\mathrm{n}$ & $\%$ & $\mathrm{n}$ & $\%$ & $\mathrm{n}$ & $\%$ \\
\hline Professional knowledge and skills & 154 & 55 & 105 & 45.65 & 100 & 40 & 359 & 47.24 \\
\hline Attitudes and values & 126 & 45 & 125 & 54.35 & 150 & 60 & 401 & 52.76 \\
\hline
\end{tabular}

It is seen in Table 3 that there are more cognitive constructs in the attitudes and values cognitive construct group $(\mathrm{n}=401,52.76 \%)$ than in the professional knowledge and skills cognitive construct group $(n=359,47.24 \%)$. Students in the 6th grade produced more cognitive constructs within the professional knowledge and skills cognitive construct group $(n=154,55 \%)$, while 7 th grade $(n=125,54.35 \%)$ and 8th grade $(n=150,60 \%)$ students produced more within the attitude and values cognitive construct group. Because the number of cognitive constructs (760) obtained was high, not all findings are given in this section. Instead, six cognitive constructs with the highest score in terms of the relative importance in each main set of cognitive construct groups are presented (with participant's grade level, number, and cognitive construct score in parentheses).

\subsubsection{Professional knowledge and skills}

There were 154 cognitive constructs at the 6th grade level. According to the relative importance, the six dominant cognitive constructs were: 1) When s/he is lecturing, there is no sound in the classroom $(6,2$, 290); 2) S/he gives important information in the course $(6,17,260)$; 3) S/he gives many examples on the subject $(6,23,240) ; 4)$ S/he lectures us with fun $(6,6,210) ; 5)$ S/he teaches very good lessons $(6,25,200) ; 6)$ S/he grades papers well $(6,5,175)$.

There were 105 cognitive constructs at the 7th grade level. According to the relative importance, the six dominant cognitive constructs were: 1) S/he knows everything (7, 16, 252); 2) S/he makes the yappers stop $(7,18,208) ; 3)$ S/he dominates the subject $(7,17,207) ; 4)$ S/he provides catchy examples $(7,2,200) ; 5)$ S/he teaches an enjoyable course $(7,22,198) ; 6)$ S/he teaches very good lessons $(7,10,190)$.

There were 100 cognitive constructs at the 8th grade level. According to the relative importance, the six dominant cognitive constructs were: 1) There is no question that s/he never knows $(8,2,230)$; 2) S/he evaluates grades nicely $(8,10,225) ; 3)$ S/he provides us with an entertaining lesson $(8,19,210)$; 4) S/he lectures clearly $(8,3,207) ; 5)$ S/he lectures nicely and in detail $(8,10,200) ; 6)$ S/he does not ignore a question by saying the question is incorrect $(8,18,190)$. 
When the cognitive constructs of the participants are examined, it can be concluded that the teachers who are seen as ideal have sub-competencies of professional knowledge competency such as knowledge of the specific field and knowledge of the education field, and sub-competencies of professional skills competency such as creating learning environments, managing the teaching and learning process, and measurement and evaluation.

\subsubsection{Attitudes and values}

There were 126 cognitive constructs in the 6th grade. According to the relative importance, the six dominant cognitive constructs were: 1) S/he does not behave angrily (6, 22, 240); 2) S/he won't get angry when we don't understand $(6,17,224)$; 3) S/he understands our language $(6,7,220)$; 4) S/he does not shout at us $(6,16,210) ; 5)$ S/he listens to our problems $(6,24,200) ; 6)$ S/he values the students and works for them $(6,1,126)$.

There were 125 cognitive constructs in the 7 th grade. According to the relative importance, the six dominant cognitive constructs were: 1) S/he behaves very well $(7,16,270)$; 2) S/he is cheerful $(7,3,250)$; 3) S/he does not judge $(7,21,230)$; 4) S/he is respectable and non-discriminatory $(7,18,180)$; 5) S/he gives importance to the lesson $(7,17,152) ; 6)$ S/he cares about the students $(7,14,104)$.

There were 150 cognitive constructs in the 8 th grade. According to the relative importance, the six dominant cognitive constructs were: 1) S/he is fair to everybody $(8,8,210)$; 2) S/he does not get mad when we ask questions $(8,10,208) ; 3)$ S/he gets along well with students $(8,7,207) ; 4)$ S/he is nice to the students $(8,15,200) ; 5) S / h e$ is a friendly teacher $(8,17,190) ; 6) S /$ he is democratic $(8,5,184)$.

When the cognitive constructs of the participants are examined, it can be concluded that the teachers seen as ideal have sub-competencies of the attitudes and values competency such as positive attitudes towards the student, communication, and cooperation.

The relative importance levels of cognitive constructs were determined by calculating the relative importance of cognitive constructs at each grade level according to total score and arithmetic mean. Table 4 presents the relative importance levels of the cognitive construct groups.

Table 4. The relative importance levels of cognitive construct groups

\begin{tabular}{ccccccccc}
\hline \multirow{2}{*}{ Cognitive construct groups } & \multicolumn{2}{c}{ 6th grade } & \multicolumn{2}{c}{ 7th grade } & \multicolumn{2}{c}{ 8th grade } & \multicolumn{3}{c}{ General } \\
& Total & $\bar{x}$ & Total & $\bar{x}$ & Total & $\bar{x}$ & Total & $\bar{x}$ \\
\hline Professional knowledge and skills & 14926 & 533.07 & 10680 & 464.35 & 10762 & 430.48 & 36368 & 478.53 \\
Attitudes and values & 11260 & 402.14 & 10965 & 476.74 & 12765 & 510.6 & 34990 & 460.39 \\
\hline
\end{tabular}

It is seen in Table 4 that in terms of the total score and arithmetic mean, the professional knowledge and skills cognitive construct group (total $=36368, \bar{x}=478.53$ ) generally has higher values. The professional knowledge and skills cognitive construct group has higher values at the 6th grade level (total=14926, $\bar{x}=533.07)$. The attitudes and values cognitive construct group has higher values at the 7 th grade level (total=10965, $\bar{x}=476.74$ ) and 8th grade level (total=12765, $\bar{x}=510.6$ ). In other words, according to 6th grade students, first of all, an ideal teacher should have professional knowledge and skills, but according to 7 th grade and 8th grade students, first of all, an ideal teacher should have appropriate attitudes and values.

When the cognitive constructs were examined, it was seen that some participants produced more than one cognitive construct with the same meaning. These repeats were treated as only one cognitive construct. The frequencies and percentages of cognitive constructs are presented in Table 5. Table 5 shows that the frequencies of repetitive cognitive constructs varied across grade levels. However, when we look at the total frequency, the cognitive constructs that these secondary school students most often expressed were: Their lessons are entertaining, they lecture better, they do not shout, cheerful, they do not discriminate, disciplined, they are democratic.

Table 5. Cognitive constructs with the highest values in terms of frequencies

\begin{tabular}{ccccc}
\hline & 6th grade & 7th grade & 8th grade & General \\
\hline Their lessons are entertaining & 18 & 11 & 13 & 42 \\
They lecture better & 16 & 9 & 2 & 27 \\
They do not shout & 10 & 5 & 9 & 24 \\
Cheerful & 8 & 5 & 8 & 21 \\
They do not discriminate & 10 & 8 & 2 & 20 \\
Disciplined & 7 & 4 & 8 & 19 \\
They are democratic & 3 & 3 & 3 & 9 \\
\hline
\end{tabular}




\subsection{Participants' examples of ideal teachers}

In the following sections, examples of the qualifications explained by the participants for an ideal teacher are presented, preceded by the participant's number, grade level, and gender, and the competencies in which these qualifications are included are summarized.

\subsubsection{Professional knowledge and skills}

P1, 6, F: "S/he teaches the lesson with a lot of fun. S/he's chatting with us. Everyone listens to her/his conversation because our teacher entertains us. But we don't always have fun, sometimes we get serious while solving difficult questions. S/he teaches the lesson very well. S/he can explain a lesson to us until we understand it. S/he is never tired of it."

P2, 6, F: "S/he teaches the lessons by coding with simple things. At the end of the lesson, s/he asks whether we have understood it or not. If someone says that s/he doesn't understand, and another one says to her/him 'How did not you understand it? It is so simple,' our teacher warns her/him. So, we can freely ask why we don't understand. I think that it's a very good thing to ask questions without any shame. If I don 't ask my questions, my head gets stuck there and I don't understand what is being told. I'm bored and I'm feeling behind."

P3, 6, M: "My teacher knows how to focus on students. For this, sometimes the students take a break and s/he entertain the students. For example, our teacher is very talented at imitating famous people. Some of our friends also begin to learn jokes that they want to tell. With other teachers, we always get bored sometimes. It's very difficult when you've done all this."

P4, 7, F: "S/he is shouting a little bit and explains in detail. S/he shuts everyone up and says (what s/he wants to say). Her/his voice is lush... Even if someone else speaks, it is not understood. Our teacher's voice is drowning it out. If someone goes down the hall, s/he will hear it. S/he teaches the lesson after silencing everyone. Once everyone is silent, no one dares to speak, because if even one person speaks, everyone looks at her/him badly."

P5, 7, M: "While writing on the board, s/he also reads the writing. S/he solves problems we can't do. Otherwise, it's boring, it's like everybody's sleeping in class. Writing is very boring sometimes, but it's easier when our teacher reads it, and we write it easily. S/he solves problems we can't do. As long as we ask, s/he solves the problem immediately."

P6, 7, F: "S/he can make the lesson interesting by doing simple activities and telling interesting things about the lesson. The other day s/he came to class with blank copy paper. S/he showed us how to fold the paper. As we folded the paper, we learned which of the lines that formed were vertical and which were parallel pieces. Then there was a strange fold of the paper. A shape appeared. Turns out our teacher made us origami. A penguin appeared. I understood the subject and had fun in that class."

P7, 8, F: "S/he uses plenty of examples and explains them through practice. If possible, s/he teaches the course with a slideshow. The slides are usually colored and the color of the slide attract our interest. For example, our IT teacher teaches the lesson with slides. There are funny cartoons on those slides. I like that very much."

P8, 8, F: "S/he tries to make the lesson fun. S/he talks to her students about things other than the course. We talk about the news, the school, and the neighborhood. Sometimes s/he tells her/his old memories and sometimes s/he tells us good things about us. Then we start the class."

P9, 8, M: "S/he enables everyone to participate in the lesson and encourages those who do not raise their hands to answer the question. Some teachers are teaching to (only) the class's hard-working students, and for those who struggle, this is very bad. After all, we want to learn, but those teachers aren't interested in us. They always give the hard-working people their say. This teacher does not always give us the right to speak. I used to be so scared of lifting a finger; I wouldn't look in anyone's eyes and I would put my head down. Now I know that my teacher will help me if I can't do anything. "

P4, 7, F: "I solve the problems in lessons. But for some reason, I get very anxious about the exams and I get low marks. Some good teachers give extra points based on our behavior in our class. There is a plus-minus list. S/he notes there how many times each student can solve problems. S/he even takes notes secretly revealing that person's behaviors."

When the statements of the participants are examined, it can be concluded that teachers who are seen as ideal have sub-competencies of professional knowledge competency such as knowledge of the specific field and knowledge of the education field. They also have sub-competencies of professional skills competency such as creating learning environments, managing the teaching and learning process, and measurement and evaluation. It is also possible to obtain information about ideal teachers' attitudes and behaviors towards students from the statements of the participants. Based on the examples of ideal teachers, qualifications that an ideal teacher should possess and the behaviors that they should exhibit within these

Int J Eval \& Res Educ, Vol. 10, No. 1, March 2021: 317 - 329 
competencies can be summarized as: An ideal teacher teaches the lesson in a nice and fun way. S/he solves the problems that the students cannot do. S/he designs the course to attract the attention of students. To do this, the teacher can organize activities or use materials during the lesson. She can take a short break, talk about interesting topics, or tell stories to get the students to focus on the lesson again. S/he enables everyone to participate in the course effectively. S/he deals with the behaviors that affect the course negatively. S/he also creates an environment in the classroom in which students can express their thoughts freely. S/he considers the student's behavior in the course as well as the test results in determining success in the course.

\subsubsection{Attitudes and values}

P1, 6, F: "S/he talks softly with students and asks us why when we can't do homework. If someone makes a habit of not doing homework, he gets the necessary punishment. For example, student's scores are deleted. But our teacher, I've never seen her/him raise his voice. I love my teacher like a parent."

P2, 6, F: "S/he gives value to students. S/he asks for our sake. S/he knows everyone in the class, s/he does her/his best if anything happens to them. For example, s/he knew my sister was taking an exam and asked me how my sister's exam was. One of our friends had a traffic accident and (the teacher) went to their home to see her/his. S/he also chats in the classroom with the students who don't have parents. S/he is always sincere with students. I love to chat with my teacher."

P3, 6, M: "S/he acts as a friend with children. S/he gets angry where s/he needs to. When children are bored, s/he makes them a little more relaxed. We don't do naughty things because we know that s/he loves and cares for children. If there is anybody who doesn't follow the rules, s/he gets very angry."

P4, 7, F: "S/he is smiling. But if the student shows disrespect, the teacher shows anger. Sometimes when the teacher comes to class, I feel comfortable. We are happy because our teacher is friendly."

P5, 7, M: "S/he does not act very hard. S/he hugs us every day and kisses us. I'm scared when a teacher is tough; after all, the teachers know a lot about us, but I don't think s/he needs to be tough with us."

P6, 7, F: "In the lesson, after our teacher warns us not to speak three times, s/he tells us softly and not too hard. S/he's very patient. S/he won't shout. She will warn anyone who interrupts the class."

P7, 8, F: "S/he has a sincere and loving relationship. S/he acts like a friend. No one in school doesn't like her/him. I wish all our teachers were like this. S/he knows all of the students, knows their names, and helps us make up with our friends. If I have a problem at school, my teacher is the first person I'm going to tell. S/he gives us some advice and sometimes speaks very well."

P8, 8, F: "S/he hugs and cares for the student and helps with everything. Our teacher first calmed the disabled student, then found out how (the problem) happened, and then s/he called his family. S/he tried to call some places and get information about how to repair the device. S/he is very concerned and does her/his best. For example, some of our friends may want to borrow money."

P1, 6, F: "What I like about him/her is that when I'm upset, s/he asks what happened. S/he empathizes with me and answers every question. Our teacher is very soft-hearted if someone has a problem; s/he will want to help. S/he will do whatever it takes for her/him."

P3, 6, M: "This teacher talks to me all the time. And when I'm around her/him, I also want to talk to her/him. My teacher smiles at me every time I see her/him, even if he's upset. When I am unhappy, he asks what's wrong."

P7, 8, F: "Unlike other teachers, s/he does not play with a phone in class. We're not allowed to use cell phones, but some teachers use their phones in class. There is no time for the phone because we are already busy. But some teachers use phones in class. They read the news and write messages. They even watch videos."

P8, 8, F: "S/he does not get distracted from the course by dealing with social media. The teacher finishes what will be done in the lesson. S/he won't leave us until it's over. Our teacher mutes the phone and sometimes speaks very briefly in case of an emergency, but s/he doesn't access the Internet."

P1, 6, F: "S/he does not discriminate between students. S/he always equal. The teacher does not make guilty persons guilty. If s/he punishes one, s/he gives the same punishment to the other. If s/he gave someone a prize, s/he gives everyone a prize if they win. I didn't see anybody be favored; s/he says s/he loves everybody. S/he even tries hard to change misbehaviors. We had a friend in our class who was teasing everyone. Our teacher worked hard with that boy so that he wouldn't do anything wrong. That boy is getting better."

P8, 8, F: "Some students may not want courses to be held. But I don't want that, because there is the (high school entrance exam) at the end of this year. This teacher comes to school unless s/he's very sick. If the courses are not held, we are left behind. Once, because of a meeting, there was no course. There was a lot of noise and everyone was shouting. Then the teacher came to the classroom, reminded us of the importance of the exam, and gave some advice. Thanks to our teacher, everybody was silent." 
P6, 7, F: "S/he does not discriminate between students who raise their hands to solve the problem. S/he equally calls those who know the solution to the problem up to the board."

When the statements of the participants are examined, it can be concluded that teachers seen as ideal have sub-competencies of attitudes and values competency such as attitudes towards the students, communication, and collaboration, and these sub-competencies are closely related. Based on the examples of the ideal teacher, qualifications that an ideal teacher should possess and the behaviors that they should exhibit within the scope of this competency can be summarized as: An ideal teacher is friendly. S/he has a calm demeanor when communicating with students. S/he never talks angrily or shouts. S/he is friendly, tolerant, and helpful to students. S/he has a friendly approach. In some cases, however, s/he may have to be tough. $\mathrm{S} /$ he makes students feel that s/he cares about their behaviors. S/he also is fair. S/he does not discriminate between students and treats everyone equally.

In this study, it was aimed to reveal the views of secondary school students related to qualifications of ideal teachers. For this purpose, a qualitative study was conducted with 76 secondary school students. As a result of the analysis of the data obtained from the repertory grid form, 760 cognitive constructs produced by the secondary school students were collected within the general competencies of the teaching profession. In the classification, professional knowledge and professional skills competencies were evaluated as a single competency, namely "professional knowledge and skills." Thus, two cognitive construct groups, "professional knowledge and skills" and "attitudes and values," were obtained. When cognitive constructs were examined, it was seen that the students gave importance to general competencies of the teaching profession and seven of the eleven sub-competencies (knowledge of the specific field, knowledge of the education field, creating learning environments, managing the teaching and learning process, measurement and evaluation, attitude towards the student, and communication and collaboration) that they contained. The students' cognitive constructs related to qualities of ideal teachers are associated with their experience, knowledge, and beliefs. The experiences of the students in the school, comparisons of good and bad teachers that occur as a result of observing teachers' behaviors, and the knowledge gained from the environment about a good teacher all have the potential to influence and shape their beliefs and cognitive constructs about ideal teachers $[31,55,56]$. In this respect, it is natural that such a situation arises because competencies such as the knowledge of legislation within professional knowledge competency or the planning of teaching within professional skills competency cannot be observed or experienced directly by students.

Studies in the literature emphasize the following qualities of an ideal teacher: knowledge of the specific field, knowledge of the education field, professional skills, personal characteristics, and professional attitudes and behaviors [30, 32, 38, 57]. For effective teaching, teachers should know the specific field, the education field (such as curriculum), and pedagogical content. Pedagogical content knowledge includes many elements such as recognition of students' developmental characteristics, recognition of their interests and needs, encouraging student learning, and guiding students. The quality of teaching is affected by the teacher's use of pedagogical content knowledge. On the other hand, the healthy implementation of the curriculum of the field depends to a great extent on the quality of classroom management, which requires that teachers have the competency of managing the learning and teaching process, seen as a professional skill. When communicating with students, their characteristics, professional attitudes, and behaviors gain importance.

The attitudes and values cognitive construct group had the highest frequency in terms of the number of cognitive constructs. Students in the 6th grade produced more cognitive constructs within the professional knowledge and skills cognitive construct group, while 7th grade and 8th grade students produced more cognitive constructs within the attitude and values cognitive construct group. The relative importance levels of the cognitive construct groups were determined both according to grade level and in general based on the scores resulting from the conversion of qualitative data obtained from the repertory grid form to quantitative data. Although the cognitive constructs that students form in general differed across grade levels, according to total scores and arithmetic means, the professional knowledge and skills cognitive construct group had higher values. The professional knowledge and skills cognitive construct group also had higher values at the 6 th grade level. The attitudes and values cognitive construct group had higher values for the 7 th grade and 8th grade. When the cognitive constructs of the participants are examined, it can be concluded that teachers who are seen as ideal have sub-competencies of professional knowledge, professional skills, attitudes, and values such as knowledge of the specific field, knowledge of the education field, creating learning environments, managing the teaching and learning process, measurement and evaluation, positive attitudes towards the student, and communication and cooperation. In similar studies, among ideal teacher qualifications, knowledge of the education field [30, 42], attitude towards the student [42, 58, 59], communication skills $[5,42,58,60]$, and classroom management $[60,61]$ have been repeated frequently.

The most striking point among the research results is that the professional knowledge and skills cognitive construct group is not dominant according to total scores or arithmetic mean at the 8th grade level. Considering the high school entrance exam in the 8th grade, the students are expected to desire to be 
successful in the exam, and the teachers should provide effective instruction for them by first mastering the knowledge of the field. However, the priority for students is to create an environment where the teacher can demonstrate the skills required for field training and teaching. Such an environment makes it necessary to deal effectively and constructively with unwanted behaviors and situations in the classroom, to take into account the interests and needs of students, and to ensure the active participation of students in learning processes.

In the fulfillment of all these conditions, the extent to which the teacher exhibits effective communication skills in his/her approach to the students is important. Similar results have been reached in previous studies $[38,60]$. In those studies, it was determined that the priorities for the qualifications of ideal teachers varied according to grade levels. It is important for students in lower grades that teachers have mastery of the field and gain knowledge and skills, while at upper levels, teachers should motivate students, address their emotions, and have appropriate communication skills. Although it is not possible to make a general judgment from the results of qualitative research, it can be said that in this study the quality of communication comes to the forefront more as the grade level increases. This may be the result of the students' developmental stages. Secondary school students are developmentally in between childhood and adolescence. As the grade level increases, the number of students entering adolescence increases. Physical and hormonal changes, emotional fluctuations, identity-seeking efforts, relationships, and new responsibilities during adolescence may exert extreme pressure on the individual. To pass through this period healthily, adolescents need the support of the people around them. Teachers are expected to be the greatest supporters of adolescents in the school environment. For this, teachers need to understand adolescents and know how to approach them.

When the cognitive constructs were examined, it was seen that some of them were frequently repeated. These cognitive constructs were: Their lessons are entertaining; They lecture better; They do not shout; Cheerful; They do not discriminate; Disciplined; They are democratic. The results of other studies that determined teachers' qualifications by using different methods also included some of these cognitive constructs $[28,29,60,61]$. Therefore, it can be said that the cognitive constructs produced by these secondary school students regarding the qualifications of the ideal teacher are concordant with the literature. On the other hand, when these cognitive constructs are examined, it is seen that the first two cognitive constructs are related to professional knowledge and skills. For students, professional knowledge and skills are both a priority and a frequently recurring quality, while attitudes and values are among the qualifications sought for ideal teachers. Ideally, teachers are expected to provide good and fun lessons, not discriminate among students, be friendly and calm in communication with students, and ensure discipline and democracy in the classroom environment.

Individual interviews were also conducted with the participants to fully understand what the participants meant by cognitive constructs, to obtain more in-depth information, and to make the analyses more accurate. During the interviews, the question "Would you please explain the qualifications of a teacher (or teachers) that you consider ideal?" was asked. The qualifications of the teachers that the participants considered ideal were classified within the "professional knowledge and skills" and "attitudes and values" cognitive construct groups. Based on their examples of ideal teachers, the qualifications that teachers should have and behaviors that they should exhibit can be summarized: An ideal teacher teaches the lesson in a nice and fun manner. S/he solves the problems that the students cannot do. S/he designs the course to attract the attention of students. To do this, s/he can use activities or materials during the lesson. S/he can take a short break, talk about interesting topics, or tell stories to get the students to focus on the lesson again. S/he enables everyone to participate in the course effectively. S/he deals with the behaviors that affect the course negatively. S/he also creates an environment in which students can express their thoughts freely in the classroom. S/he takes into consideration the student's behavior in the course as well as the exam results in determining success in the course. S/he is friendly. S/he has a calm demeanor when communicating with students. S/he never talks angrily or shouts. S/he is friendly, tolerant, and helpful to students. S/he has a friendly approach. In some cases, however, s/he may have to be tough. S/he makes students feel that s/he cares about their behavior. For the ideal teacher, the lesson takes precedence. S/he is also fair. S/he does not discriminate between students and treats everyone equally.

\section{CONCLUSION}

It can be said that ideal teachers should have ideal attitudes and values as well as professional knowledge and skills. This discourse is structurally similar to the results of previous studies. In this study, the views of secondary school students on ideal teacher qualifications were revealed by using the repertory grid technique and interview technique. Considering that the secondary school students' cognitive constructs related to ideal teacher qualifications and the priority of the constructs differed even in the classroom levels, 
it is thought that studies to be conducted on different educational levels will provide a wider perspective on ideal teacher qualifications. Furthermore, a holistic understanding of the studies carried out with different groups of participants (school administrators, teachers, prospective teachers, students of different educational levels, and school types) can contribute to the field by revealing similar and different qualifications of the ideal teacher.

\section{REFERENCES}

[1] M. Şişman, Öğretmenlik mesleğine giriş. Ankara: Pegem Yayıncılık, 2000.

[2] S. Demir, "İlköğretim öğretmenlerinin etkili öğretimi gerçekleştirme düzeylerinin incelenmesi," Uluslararası Hakemli Sosyal Bilimler E-Dergisi, vol. Kasım- Aralık 2012, no. 33, pp. 1-20, 2012.

[3] A. Balc1, "Etkili okul”, Eğitim ve Bilim, vol. 12, no. 70, pp. 21-30, 1988

[4] M. M. Karc1, "Öğrenci gözüyle ideal öğretmenin özellikleri: Gazi mesleki ve teknik anadolu lisesi örneği," Milli Eğitim Dergisi, vol. Kış 2016, no. 209, pp. 80-101, 2016.

[5] E. Karadağ, "Okul müdürlerinin niteliklerine ilişkin olarak öğretmenlerin oluşturdukları bilişsel kurgular: Fenomenolojik bir çözümleme," Ĕgitim ve Bilim, vol. 36, no. 159, pp. 25-40, 2011.

[6] N. Baloğlu and E. Karadağ, "Öğretmen yetkinliğinin tarihsel gelişimi ve Ohio öğretmen yetkinlik ölçeği: Türk kültürüne uyarlama, dil geçerliği ve faktör yapısının incelenmesi,” Kuram ve Uygulamada Eğitim Yönetimi, vol. 13, no. 56, pp. 571-606, 2008.

[7] R. Öncül, Eğitim ve eğitim bilimleri sözlüğ̈̈. İstanbul: MEB Yayınları, 2000.

[8] R. Tuck, "An introductory guide to national qualifications' frameworks: Conceptual and practical issues for policymakers," Geneva: International Labour Office, 2007.

[9] MEB, Öğretmenlik mesleği genel yeterlikleri. Ankara: Öğretmen Yetiştirme ve Geliştirme Genel Müdürlüğü, 2017.

[10] TED, Ö̆gretmen yeterlikleri. Ankara: Adım Okan Matbaacılık, 2009.

[11] M. Özkan, and H. İ. Arslantaş, "Etkili öğretmen özellikleri üzerine sıralama yöntemiyle bir ölçekleme çalışması," Trakya Üniversitesi Sosyal Bilimler Dergisi, vol. 15, no. 1, pp. 311-330, 2013.

[12] Kentli, F. D, "İdeal öğretmenlerin disiplin modelleri: Bir anlatı çalışması,” Mersin Üniversitesi Eğitim Fakültesi Dergisi, vol. 12, no. 1, pp. 290-302, 2016.

[13] M. Çelikten and N. Can, "Yönetici, öğretmen ve veli gözüyle ideal öğretmen," Selçuk Üniversitesi Eğitim Fakültesi Dergisi, vol. Aralık 2003, no. 15, pp. 253-267, 2003.

[14] N. Özabacı and B. Acat, "Öğretmen adaylarının kendi özellikleri ile ideal öğretmen özelliklerine dönük algılarının karşılaştırılması,” Kuram ve Uygulamada Eğitim Yönetimi, vol. 21, no. 42, pp. 211-236, 2005.

[15] D. Aaronson, L. Barrow, and W. Sanders, "Teachers and student achievement in the Chicago public high schools," Journal of Labor Economics, vol. 25, no. 1, pp. 95-135. 2007.

[16] L. C. Cavalluzzo, "Is National Board Certification an effective signal of teacher quality?" (Report No. IPR 11204), Alexandria, VA: The CNA Corporation, 2004.

[17] D. K. Cohen and H. C. Hill, "Instructional policy and classroom performance: The mathematics reform in California,” (CPRE Research Report Series RR-39), Teachers College Record, vol. 102, no. 2, pp. 294-343, 2000.

[18] L. Darling-Hammond, "Teacher quality and student achievement: A review of state policy evidence," Education Policy Analysis Archives, vol. 8, no. 1, pp. 1-44, 2000.

[19] D. D. Goldhaber, and D. J. Brewer, "Evaluating the effect of teacher degree level on educational performance," in NCES State Data Conference, 1996, pp.1-17.

[20] E. A. Hanushek, J. F. Kain, D. M. O’Brien, and S. G. Rivkin, "The market for teacher quality,” (Working Paper No. 11154), Cambridge: National Bureau of Economic Research, 2005.

[21] J. E. Rockoff, "The impact of individual teachers on student achievement: Evidence from panel data," American Economic Review, vol. 94, no. 2, pp. 247-252, 2004.

[22] H. C. Hill, B. Rowan, and D. L. Ball, "Effects of teachers' mathematical knowledge for teaching on student achievement," American Educational Research Journal, vol. 42, no. 2, pp. 317-406, 2005

[23] MEB, "Uluslararası öğrenci değerlendirme programı PISA 2015 ulusal raporu," Ankara: Ölçme ve Değerlendirme Genel Müdürlüğ̈̈, 2015

[24] MEB, "Akademik becerilerin izlenmesi ve değerlendirilmesi (ABİDE raporu)," Ankara: Ölçme ve Değerlendirme Genel Müdürlüğ̈̈, 2016.

[25] J. Schacter, and Y. M. Thum, "Paying for high- and low-quality teaching," Economics of Education Review, vol. 23, no. 4, pp. 411-430, 2004

[26] Wenglinsky, "How schools' matter: The link between teacher classroom practices and student academic performance," Education Policy Analysis Archives, vol. 10, no. 12, pp. 1-30, 2002.

[27] J. J. Beishuizen, E. Hof, C. M. van Putten, S. Bouwmeester, and J. J. Asscher, "Students' and teachers' cognitions about good teachers," British Journal of Educational Psychology, vol. 71, pp. 185-201, 2001.

[28] M. Bullock, "What makes a good teacher? Exploring student and teacher beliefs on good teaching," Rising Tide, vol. 7, pp. 1-30, 2015.

[29] L. Ciascai and L. E. Vlad, "Perception of school and university students of ideal teacher behaviours (11) pilot study," Acta Didactica Napıcensia, vol. 7, no. 3, pp. 49-58, 2014

[30] Ş. Çetin, Ş. "İdeal öğretmen üzerine bir araştırma”. Milli Eğitim Dergisi, vol. Ocak-Şubat- Mart 2001, no. 149, pp. 29-37, 2001.

Int J Eval \& Res Educ, Vol. 10, No. 1, March 2021: 317 - 329 
[31] K. P. Murphy, L. A. M. Delli, and M. N. Edwards, "The good teacher and good teaching: Comparing beliefs of second-grade students, preservice teachers, and inservice Teachers," The Journal of Experimental Education, vol. 72, no. 2, pp. 69-92, 2004.

[32] S. Telli, P. Den Brok, and J. Çakıroğlu, "Teachers' and students' views of the ideal teacher," Eğitim ve Bilim, vol. 33, no. 149, pp. 118-129, 2008.

[33] Ş. Sezer, "Okul yöneticilerinin ideal öğretmen niteliklerine ilişkin bilişsel kurguları: Repertory grid tekniğine dayalı fenomenolojik bir çözümleme,” Eğitim ve Bilim, vol. 41, no. 186, pp. 37-51, 2016.

[34] L. Björklund, "The repertory grid technique: Making tacit knowledge explicit: Assessing creative work and problem-solving skills," in H. Middleton, Ed. Researching Technology Education. Rotterdam: Sense Publishers, 2008, pp. 46-69.

[35] Y. Hillier, "Informal practitioner theory: Eliciting the implicit," Studies in the Education of Adults, vol. 30, no. 1, pp. 35-52, 1998.

[36] F. Tanhan, "Repertory grid görüşme tekniğine dayalı olarak okul psikolojik danışmanlarının niteliklerinin incelenmesi," Türk Psikolojik Danışma ve Rehberlik Dergisi, vol. 5, no. 40, pp. 186-197, 2013.

[37] Ş. Ay and İ. Yurdabakan, "Öğretmen adaylarına göre etkili öğretmen özellikleri ve bu özellikler açısından özyeterlik algıları," Mehmet Akif Ersoy Üniversitesi Ĕ̈itim Fakültesi Dergisi, vol. 33, pp. 148-166, 2015.

[38] A. Aypay, "İlk ve ortaöğretim öğretmenlerinin davranış alışkanlıkları ve "iyi öğretmen" özelliklerine ilişkin alg1ları," İlköğretim Online, vol. 10, no. 2, pp. 620-645, 2011.

[39] P. Kutnick, and V. Jules, "Pupils' views of a good teacher: a developmental perspective from Trinidad and Tobago," Br J Educ Psychol, vol. 63, no. 3, pp. 400-413, 1993.

[40] G. Numanoğlu, and Ş. Bayır, "Bilgisayar öğretmen adaylarının öğretmenlik mesleği genel yeterliklerine ilişkin görüşleri," Ahi Evran Üniversitesi Kırşehir Eğitim Fakültesi Dergisi, vol. 10, no. 1, pp. 197-212, 2009.

[41] C. Şimşek, "Yetişkinlerin düşünce hayatında olumlu iz bırakan öğretmenlerin ortak kişilik ve davranış özellikleri," Eğitim ve Öğretim Araştırmaları Dergisi, vol. 4, no. 3, pp. 131-141, 2015.

[42] İ. Kozikoğlu, "Prospective teachers' cognitive constructs concerning ideal teacher qualifications: A phenomenological analysis based on repertory grid technique," International Journal of Instruction, vol. 10, no. 3, pp. 63-78, 2017.

[43] A. Yıldırım, and H. Şimsek, "Sosyal bilimlerde nitel araştırma yöntemleri” Ankara: Seçkin Yayınevi, 2005.

[44] J. W. Creswell, Nitel araştırma yöntemleri, (M. Bütün and S. B. Demir, Trans.). Ankara: Siyasal Kitabevi, 2015.

[45] T. Baş and U. Akturan, Nitel araştırma yöntemleri. Ankara: Seçkin Yayıncılık, 2008.

[46] Ş. Büyüköztürk, K. E. Çakmak, Ö. E. Akgün, Ș. Karadeniz, and F. Demirel, Bilimsel araștırma yöntemleri. Ankara: Pegem Akademi, 2009.

[47] D. Jankowicz, Easy guide to repertory grids. West Sussex: John Wiley and Sons Ltd., 2004.

[48] G. A. Kelly, The Psychology of personal constructs. New York: W.W. Norton \& Company, 1955.

[49] R. Bell, "A note on aligning constructs," Personal Construct Theory and Practice, vol. 7, pp. 42-48, 2010.

[50] F. Fransella, R. Bell, and D. Bannister, A manual for repertory grid technique, (2nd ed). Chichester: Wiley, 2004.

[51] D. Stergiadis, "Persona modeling by crowdsourcing using the repertory grid technique," Unpublished master thesis, Linköping University, Linköping, 2017.

[52] N. Cemaloğlu, "Veri toplama teknikleri: Nicel ve nitel," in A. Tanrıöğen (Ed.) Bilimsel Araştırma Yöntemleri, pp.113-164, Ankara: Anı Yayıncılık, 2012.

[53] E. Kuș, Nitel ve nicel araştırma teknikleri. Anı Yayıncılık, Ankara, 2007.

[54] M. B. Miles and A. M. Huberman, Qualitative data analysis: An expanded Sourcebook, (2nd Ed). Thousand Oaks: Sage Publications, 1994.

[55] T. Bird, L. Anderson, B. Sullivan, and S. Swidler, "Pedagogical balancing acts: A teacher educator encounters problems in an attempt to influence prospective teachers' beliefs," Teaching and Teacher Education, vol. 9, no. 3, pp. 253-267, 1993.

[56] V. Richardson. The role of attitudes and beliefs in learning to teach. In J. Sikula (Ed.). Handbook of research on teacher education. New York: Macmillan, 1996, pp. 102-119.

[57] S. Arnon and N. Reichel, "Who is the ideal teacher? Am I? Similarity and difference in perception of students of education regarding the qualities of a good teacher and of their own qualities as teachers," Teachers and Teaching, vol. 13, no. 5, pp. 441-464, 2007.

[58] C. Rusua, L. Soitub, and O. Panaite. "The ideal teacher". Theoretical and investigative approach Procedia - Social and Behavioral Sciences, vol. 33, pp. 1017 -1021, 2012.

[59] B. Ubuz and S. Sarı, "Sınıf öğretmeni adaylarının iyi öğretmen olma ile ilgili görüşleri," Ondokuz Mayıs Üniversitesi Eğitim Fakültesi Dergisi, vol. 28, pp. 53-61. 2009.

[60] M. Ulusoy, "Sınıf öğretmeni adaylarının ideal öğretmen ve mesleki yeterliklerle ilgili değerlendirmeleri," Uşak Üniversitesi Sosyal Bilimler Dergisi, vol. 6, no. 4, pp. 324-341, 2013.

[61] M. Çalışkan, A. N. Işık, and Y. Saygın, "Prospective teachers' perception of ideal teacher," Elementary Education Online, vol. 12, no. 2, pp. 575-584, 2013 